\title{
One Icon, Two Audiences: How the Denver Art Museum used their new building to both brand the city and bolster civic pride
}

Iconic architecture can draw global attention while simultaneously speaking to local audiences. In 2006, the Denver Art Museum opened an iconic new wing that help brand the city as cultural city_-for both external and internal audiences. Based on analysis of interviews with stakeholders and archival documents, I demonstrate that the Hamilton Building project was used both to brand the city for potential tourists and to engender civic pride in Denver residents. This research provides a complex understanding of what roles iconic architecture plays in a city.

Key Words: Iconic architecture, Denver Art Museum, Daniel Libeskind, Flagship projects, Audiences, civic pride

\section{Introduction}

Architectural style speaks about who a city represents and welcomes as citizens (Holliday 2009), and iconic buildings can be used by institutions to foster legitimacy in the eyes of the public (Patterson 2012). Architecture is often studied as participants in these two different dialogues, as appealing to global audiences or as responding to local needs. In this paper, I use a project in Denver to show how buildings can be used to help institutions connect both with global audiences and local ones. Opened in 2006, the Denver Art Museum’s (DAM) new wing (Figure 1) was enlisted by Museum and City leaders to do both of those things, simultaneously operating as an agent of city branding to audiences outside of Denver and fostering a sense of civic pride to residents of the Denver metropolitan area. The wing provided space for multiple traveling or temporary exhibitions, two floors on which to exhibit pieces from the Modern and Contemporary permanent collection, an interactive studio devoted to exhibition-related hands-on activities, a 
large lecture hall, and an expanded gift shop. The project also included converting one block of public street to a pedestrian plaza and building a parking garage wrapped by luxury condominiums, a hotel, and spaces for retail (Figure 2). Located near the Civic Center, it was part of a cultural regeneration project, operating under the common assumption that consumption of arts and cultural activities can "act as a catalyst for both activity and investment" (Wansborough and Mageean 2000, 184). The Hamilton Building, as the new wing was called after a major donor and DAM board chair, was a result of the DAM's desire to draw visitors and make itself known on a national stage. It was a classic example of the Bilbao Effect, which has been shaping ideas about the relationship between architecture, cities, and museums for twenty years. Simultaneously, the new building provided an opportunity to connect with local audiences and engender civic pride in a city coming into its own as a regional cultural center and overcoming a decades-old stereotype of being little more than a cow town in the middle of the country. While these two different goals—branding the city for external audiences and fostering pride in local audiences - are often looked at separately, in this paper, I bring them together to demonstrate how a single building can fulfill both roles.

\section{Branding and the Bilbao Effect}

The turn of the millennium was an "age of museum madness," where each museum vied to “erect the splashiest most acclaimed signature building” since the last one (West 2006, 220). These "new museums" (Newhouse 2006; Message 2006b, 2006a) go far beyond just housing art to include "an engaging entry pavilion and more specialized galleries...a top-flight restaurant, and an amply stocked gift shop," in addition to an education center and an auditorium (Schulze 2001, 23), incorporating the “dining, shopping, education, entertainment, and social needs” of their customers (Tilden 2004, 7). Internationally known architects participate in competitions for 
such commissions, often presented to the public as part of the application and publicity process, raising the profile of the project (Rybczynski 2002). Institutions "trade on spectacle, commerce and cultural tourism” in an effort to reach for new audiences (Fyfe 1996, 213) essentially using "spectacular buildings by celebrity architects...to revitalize struggling post-industrial cities and put their name[s] on the global tourist map” (Greenberg 2008, 29).

One of "the most ambitions attempts to date to associate an art museum with urban renewal” (Newhouse 2006, 246), the Guggenheim Museum at Bilbao is the eponymous example of the Bilbao Effect. Located along the water in an old industrial district, the building is a work of art, "as challenging, distinct, and beautiful as anything an artist might put inside" (Henderson 1998, 35). Situated in an industrial city with a declining population, a dwindling economic base, and regular violence by separatists, the museum, with curvilinear titanium sides and a form that resembles an artichoke, a flower, or a fish, along with the art it houses, was to be part of the rejuvenation of Bilbao and part of its transformation into a global tourist site (Brawne 1998, 48; Fraser 2006). Juan Ignacio Vidarte, director of the Guggenheim Bilbao, asked Frank Gehry, the architect, to design a "building like the Sydney Opera House, which would provide a visual identity and transform the city of Bilbao” (Isenberg and Gehry 2009, 136). The Bilbao Museum cost \$166 million to build, but provides \$30 million in annual tax receipts (West 2006), and is essentially “the founding work of art of the Bilbao Guggenheim” (Zulaika 2003, 126).

The government of Bilbao made a deal with the Guggenheim for a museum and a building calculated to take advantage of the globalizing culture economy (Moxey 2005). The deal arguably succeeded: the museum has been credited with improving the city and stimulating the economy. Essentially, the Guggenheim Museum "put Bilbao on the map” (Ana Maria Guasch and Zulaika 2005, 17), drawing over 800,000 visitors a year. Moreover, the iconic 
building helped increase sponsorship for the museum, the core of the new tourism economy (Plaza 2000, 2007). The Bilbao Guggenheim museum was so successful—earning the city’s investment back within seven years, drawing tourists from across the globe, and making Frank Gehry and Bilbao household words around the world — that museums across the globe have tried to copy it (Plaza 2000, 2008).

The Guggenheim Museum at Bilbao represents a "new moment in the evolution of the society of the spectacle and its global architectural representations” (Ockman 2004, 228), where global ideas and global money impact building projects that might otherwise be a purely local concern. While cities used to be defined by their monumental architecture, now they are defined by iconic architecture—symbols of something without having to symbolize anything, designed by architects who are themselves competing in a global market for high commissions (Jencks 2005, 2006). In a globalizing world where cities are competing for the attention of global travelers, buildings help brand the city and draw tourists. Architecture is used in branding, with cities using architecture "to elevate their position in the global village" (Klingmann 2007, 2). Moreover, the transnational capitalist class plays a large role in how globalizing cities use iconic architecture for urban intervention (Sklair 2005). Iconic buildings require the 21st century's ease of air travel for the global architects to work internationally and to allow national and international visitors to come to the building, and global media to disperse the images (McNeill 2009), creating an environment where often our experience of architecture and the city is mediated by the popular and tourism press (Lasansky and McLaren 2004). Corporate funding and culture requires iconic buildings to get attention and draw the necessary capital (Jencks 2006). Cities give money for museums and museum buildings to demonstrate collective cultural capital in competition with other cities, vying for regional or global city status (King 1991; 
Domosh 1996; Witcomb 2003; Brenner and Keil 2006). They—and the iconic architecture that houses them —are part of the creation of what Hannigan (1998) calls a "fantasy city," or a city to be consumed, to be checked off a list of experiences (Lefebvre 1996). Largely because of the visible success of the Bilbao, cultural institutions are thought to draw educated residents and international tourism (Florida 2005; Dicks 2004).

\section{Identity and Local Audiences}

While cultural consumption has economic implications on a global scale it cannot be the sole driver of rejuvenation (Zukin 1991; Clark 2004); successful projects also include a diverse economy, integration of the market, and an increase in the overall productivity of the city (Grodach 2008; Plaza 2006). The arts can be an important source of employment for cities, and urban policy can help support that employment (Grodach 2016). As national and state governments retreat, regions and cities are becoming "more important decision arenas” (Clarke and Gaile 1998, 3). Public/private partnerships emerged in the 1980s as part of a more entrepreneurial development strategy, with the "public" as the junior partner (Greenberg 2008). However, not all flagship projects result in an increased presence of global capital (Spaans 2004); they also function as a "catalyst" for local arts activities in addition to attracting tourists (Grodach 2008, 496).

In any project, concerns are not only about global tourism and private sector funding, but also about local audiences. With iconic buildings often understood as a large sculpture in the city-scape, they can both reflect local identity and contribute to place promotion, as public art does (Mccarthy 2006). Iconic buildings and innovative designs which are not tied to historical symbolism can allow people to make up their own meaning and offer a common language for diverse populations (Gospodini 2004). Self-identity is intertwined with place identity, as our 
built environment is the setting for and the product of social practices (Erickson and Roberts 1997; Lefebvre 2011). It also can help create a sense ownership of culture and cultural institutions in local residents, and pride in their government (McClellan 1999; Duncan 1995).

Thus, museum building projects, especially those since the wild success of the Guggenheim Museum in Bilbao, often have goals beyond preserving and displaying art. Museums are often the flagship institution in a larger project of neighborhood revitalization which use iconic architecture to increate tourism and investment. Simultaneously, the same iconic buildings are called on to create a local identity and foster civic pride.

\section{Methods}

To better understand how a single building can accomplish the twin goals of communicating with two different audiences, I use the Denver Art Museum’s Hamilton Building as a case study. I draw on interviews conducted with 63 stakeholders-including designers, administrators at both the Museum and the City, residents of Denver, volunteers and members of the Museum, residents of the luxury condominiums across the plaza, and DAM board members—as well as analysis of newspaper articles in an extensive archive at the Central Public Library in Denver. Collectively, all interviews, newspaper articles, and other printed media such as brochures and annual reports were considered "sources" which I coded in multiple rounds of analysis. This paper focuses on the sources that mentioned the Hamilton Building as symbolic of something. Further coding yielded categories of comments as referring to the Hamilton Building as a symbol for the institution of the Denver art museum or for the City of Denver. The DAM used the building in two different ways; first, to brand the city to identify the city with arts and culture, and second, to engender pride in residents whose tax dollars supported the project. Two thirds of the sixty comments about the connection between Denver and the Museum from 
interviews and print media were about the city getting a symbol to help with branding, while the remaining third of the comments talked about the symbolism or branding opportunity for the Denver Art Museum. In the next sections, I present the findings about national audiences and city branding first, followed by findings about local audiences pride in the city and the museum.

\section{Denver: representing culture in a cow town}

Denver sees itself in transition, from an industrial center to a large regional city with a more complex economy, from a western town to a city of leisure and culture (Palmer 2012). Like many regional cities, it is trying to distinguish itself with architecture and infrastructural investments. Some long-term residents worry that outsiders think of Denver as a "cow town,” an idea reflected in headlines such as “Not Just Another Cow Town” (Heathcote 2006) and “Denver: The Cow Town with Culture, and Proud of It” (Krakauer 1993). One DAM volunteer I interviewed in 2012 said that he loved "the feast of architectural styles our little cow town haswe're not the center of culture, but we try” (emphasis mine). One staff member said that Denver is a regional city that wants to be a national city, and that "the Hamilton Building is one more feather in the cap of a national-caliber city;” another said that the Hamilton Building was really a tool for the city boosters to show that Denver is a big city and not a cow town. Six different comments mentioned Denver’s image as a “cow town.”

At the last Census, Denver had over 600,000 residents, making it the 26th-largest city in the country; with significant growth in the past five years, the population is estimated to now be approaching 700,000 (Murray 2017). When taking into account the metropolitan area population, Denver moves up to 21st-most populated metro area in the United States, with over 2.5 million people in the statistical area (US Census Bureau 2010). Either those who call Denver a cow town have not caught up to the national image of Denver as measured by polls or the marketing 
strategy is working, because Denver ranks well in national polls of architectural accomplishment. The international design firm RMJM Hillier conducted a national survey of perceptions of different cities, including questions about infrastructure and urban design, architecture, arts and culture employment, and other design-focused metrics (RMJM Hillier Communications Department 2008). They found Denver ranked eighth, in the top ten with New York, Boston, Seattle, San Francisco, and Washington, DC. When the ranking is focused purely on architecture, Denver slips back into a position closer to its rank by size, ranking twentieth, according to a national poll by CNN Headline News and travelandleisure.com (Travelandleisure.com, CNN Headline News, and Pearson Education, Inc. 2008). Denver is in the top ten most educated cities in the US, and some sources place it as the second-most educated population, next to either New York or Washington, DC (Heathcote 2006; Nicholson 2006; CBS News 2010). Moreover, Denver is a center for the arts, with a strong concentration of arts employment in 2000, which has declined somewhat since (Grodach 2016).

Of the comments that referred to the Hamilton Building as a symbol for the city spoke about it as a marketing tool for the city, to either increase national or international attention for Denver, or to increase the standing of Denver as a cultural or global city. A high level administrator said in an interview that part of the goal of the Hamilton Building was to build such a landmark that people would go to Denver to see it, and Fredrick C. Hamilton, Chairman of the Board, talked about using the building to market the museum and Denver as a tourist destination (Filler 2006). The Hamilton Building was supposed to receive as much world-wide attention "as anything that's happened in Denver" (Reuteman 2004) when it opened. With the Guggenheim Museum in Bilbao far exceeding estimated visitors when it first opened, expectations were high for this Bilbao-effect building. Especially once Daniel Libeskind was 
chosen as the architect for the World Trade Center, Denver and the DAM expected a boost in visitations from the additional publicity that would bring (MacMillan 2003a, 2003b).

But the new wing was not just going to garner attention for Denver and increase tourism. It was also meant to be a symbol of culture cachet; a sign that Denver is had outgrown its cow town roots and is now a national city with a strong arts and culture scene. The head of Denver's Marketing Bureau, addressed the Hamilton Building's role in Denver's marketing strategy, saying that a building alone does not drive tourism, but that a building can add to branding a city, and the Hamilton building is one of the top ten things they showcase. The Hamilton Building provides a new, state-of-the-art exhibit space, which has a domino effect: it allows exhibits such as the blockbuster traveling exhibit on King Tut, for example, to exhibit in Denver, which draws people. Thus, Denver and the Denver Art Museum, in choosing an iconic new building, have invoked the Bilbao Effect to place Denver as a cultural center in a western, urbanizing region of the United States. Many saw the Hamilton Building as a way to demonstrate that Denver was a national-caliber city and to reach national and international audiences with its publicity. Eugene Dilbeck, the Executive Director of the Denver Metro Convention and Visitors Bureau, said that the new building could bring urban-oriented tourists to Denver, which "would put Denver in the league of a Chicago or San Francisco” (quoted in Aguilar 2002). And a DAM staff member said that the Hamilton Building showed that Denver is becoming a cultural place; a newspaper reported that the civic leaders of Denver launched "an international effort to brand Denver as a cultural Mecca” in conjunction with the Hamilton Building’s opening (Dunn 2006a).

\section{The Art Museum: representing the people}

Marketing relies on images, which might not reflect the lived experiences of the citizens of the city (Erickson and Roberts 1997). But in the case of the DAM, administrators in both the city 
and the museum worked to enage local audiences. . The DAM was an entrepreneurial strategy on the part of the city, as a downtown flagship project to catalyze private sector investments and pursue economic growth through tourism and city image (Grodach and Loukaitou-Sideris 2007). Because of a unique funding structure, however, the Denver Art Museum intentionally reached out to local audiences as well as national and international ones, conscious of their need as an institution to use the building to increase public legitimacy. The DAM invited the public to observe the process and participate in discussions about it to help create a sense of pride in the institution and instill the feeling that the building belonged to the public, not just to a few elites. In the next sections, I talk about the funding structure of the DAM and the efforts it made to reach out to local audiences to create a sense of local pride and ownership.

\section{Funding the Denver Art Museum}

In the mid-1970s, fifty per cent of the operating budget of the DAM was covered by municipal subsidy. In 1981, however, Colorado in general stopped subsidizing cultural agencies, and the City subsequently reduced funding of the DAM (Harris 1996, 47-48). Now, the DAM is an independent agency with its own not-for-profit status, but there are still vestiges of the old connection. For example, the City owns the land, while the Museum owns the buildings, but the City has paid for some repair of the older building, and throughout the years the voters of Denver have approved bonds for the Museum buildings.

The Directors of some Denver cultural agencies, including the Museum, responded to the dwindling tax support of their institutions by proposing a separate, renewable tax. Since 1989, the Denver Art Museum has been partially supported by funds from the Science and Cultural Facilities tax. The Science and Cultural Facilities District (SCFD) distributes money collected through a point-of-sale tax of one-tenth of one per cent in the seven counties in and around 
Denver, which is divided up between 300 cultural organizations in the Denver Metro area. Five institutions - the Denver Art Museum, the Denver Botanic Gardens, the Denver Center for the Performing Arts, the Denver Museum of Nature and Science, and the Denver Zoological Gardens-are Tier I organizations, meaning that they collectively receive $65.5 \%$ of each year’s distributions, as written into the statute. SCFD allocations must be used for general operating expenses and not capital campaigns or buildings. From 1989 to 2010, these tax receipts funneled \$100 million to the DAM for general operating expenses, or around a quarter of the general operating budget. One of the results of the SCFD is that all the Tier I institutions have "free days,” where anyone with a Colorado Identification is admitted free of charge (Science and Cultural Facilities District 2009, 3). The SCFD is a boon to both the institutions that receive money and to the public. According to SCFD staff, the public funding makes it possible for cultural institutions to experiment, while a "sunset" clause keeps them aware of customer and patron wants and needs. Many people credit the SCFD sunset clause with the DAM's concern with appealing to a broad audience: one quarter of their funding is subject to broad voter approval.

In addition to a portion of their operating budget coming from voter-approved public money, the initial funding for the new wing came from a public bond, which also had to be approved by local voters. In 1999, after having visited Bilbao during the opening of the Guggenheim Museum and convincing the DAM board that an iconic building was right for Denver, the Museum's Executive Director Lewis Sharp asked the Mayor if the city would put forward a bond issue to raise some of the money necessary to expand the DAM. A new wing was necessary to display the Modern and Contemporary collection, which for nearly a decade had not had permanent gallery space in the Museum, and to provide up-to-date facility for hosting 
traveling exhibitions with stringent climate control requirements. An iconic new wing, Sharp argued, would also be a symbol for Denver and for the museum. The bond passed, and because of this public nature of the funding, the museum worked hard to engage the public. The new building was going to be the public face of the museum and could represent the SCFD in many peoples' minds, impacting the renewal vote. A local architect who worked on the project corroborated this sentiment, saying that the selection committee wanted the building to be celebrated by the community, so they actively sought community participation. And, according to an emeritus administrator, the process engaged the public widely because of the bond funds, which gave the DAM the responsibility to communicate with the public.

Once the bond was secured, creating momentum for further fundraising (Dunn 2006b), a selection committee chose the architect (as opposed to a particular design (Sinisi 2000)), sending out a request for proposal for a $\$ 42$ million addition. The public committee appointed to help find the architect for the Hamilton Building was charged with finding an international architect who would make a signature building, to attract gifts and collections, not only from Colorado but also from the around the world (Barnes-Gelt 2006). The selection committee invited experts to speak to staff and trustees, conducted focus groups with staff, trustees and members, and eventually invited five shortlisted candidates to Denver for interviews (Sharp and Hamilton 2000). After the interviews, the Committee selected three architects for the final short list: Arata Isozaki, Daniel Libeskind, and Thom Mayne. The DAM displayed photographs of buildings by the finalists and invited the public to comment (Ditmer 2000a), beginning the process of involving the public in the process of design. The issues for the top three architects to address with the new building were its physical relationship to the existing wing and the larger urban context, bringing up questions of architecture and urban design (Chandler 2000). 
In the end, the committee selected Daniel Libeskind as the architects for three main reasons. First, sources mentioned his personality as an important part of their decision. Sources called him "personable,” "engaging,” and "gracious,” as well as "magical,” "lyrical,” and "unique.” Second, and more relevant to the argument of this paper, Libeskind was selected based on the strength of his designs, particularly the Jewish Museum in Berlin. That building was so effective that hundreds of thousands of people visited the empty building before the collections had been installed, just to experience the space as its own evocative experience. Third, and equally important to the argument here, Libeskind was selected because of the enthusiastic way he talked about the project and about Denver. He would say things like, "it’s going to be a terrifically unusual building, I think—a giant titanium-covered sculpture, rolling like a landscape, full of dramatic surprises” (Libeskind 2004, 107); or he would wax poetic about the Colorado landscape, saying "the shape of the extension of the Denver Art Museum...came to me as I flew over the city and could take in its full symphonic presence from above. I am struck by geology—the shifting of tectonic plates, and the unholy forces they unleash, causing whole mountain ranges to be thrust up from the earth’s crust” (Libeskind 2004, 8). Moreover, he advocated for involving the public, saying: "we live in the marketplace, not only in terms of selling and buying but in the marketplace of ideas. It's a democratic city, democratic country, and that's how civic projects get developed...Either you interact and communicate what you're doing or you're really cynical and should not be involved in civic art" (quoted in MacMillan 2003b).

\section{Engaging the Public}

After the model was unveiled, public comment was invited—Libeskind's presentation of the model followed by a panel of "museum, civic, and planning experts answering questions" was 
broadcast on Channel 8, with a website set up for comments (KDTV Channel 8 2001). More than 400 people attended the preliminary concept forum in July 2000 (Ditmer 2000b).

Some 700 people attended a public forum on the design—a record for Denver (Chandler 2001). Then, in May 2005, Libeskind gave a lecture, which the DAM estimated was attended by approximately 1,700 people, some of whom in line for hours for the free tickets. One visitor was quoted as saying, "I feel like this is part of history — to have a world-renowned architect here. I think it’s very exciting” (MacMillan 2005; Carman 2005).

As construction on the Hamilton Building started, the model was displayed in the existing building overlooking the construction site, with a notebook for public comment. Some of the comments were negative- “I think this is one of the ugliest designs I have ever seen...I'll not donate” —and some were positive: “Hopefully this will put Denver on the map as an 'art town'” (quoted in Booth 2003). Regardless of the tenor of the comments, though, they demonstrated an engagement with the process and with the design; one staff member said that it did not matter if people liked or disliked the building, as long as the public was talking about it, broadly engaging with architecture and symbolism for the museum.

The Hamilton Building was supposed to communicate about the Museum to the public: it is a "work of art in itself, and a marker for what is happening inside," according to an emeritus staff member commenting in an interview. He went on, "the Museum organization wants to engage the community, and the building was a tool for that engagement, and a reflection of the innovation occurring inside the walls.” All that work helped to increase local attachment to the museum and pride in the City. One designer who worked on the building said that "it changed the way Denver viewed itself.” Architecture alone does not determine how we think about projects-it also matters how city leaders talk about the projects (Pojani and Stead 2015). 
According to then-Mayor Hickenlooper, Denver is a rising city with "quite a bit of civic pride” (West 2006). A large number of corporate and non-profits that booked events in the building: over forty bookings in the first two months the building was open (Dunn 2006c). The DAM uses a picture of the Hamilton Building for its Facebook profile, instead of a logo like many other museums (Figure 3). One staff member in Young Adult Programming said that the new building gave the Museum a chance to imagine what could go in the space and how the "Museum messages itself.” Finally, staff held hope for the building improving the Museum's status or reputation; for example, one longtime volunteer explained, if you have a lower-quality collection, you have to have a symbolically big building to make people "come and see.”

\section{Conclusions}

In the decade after the Hamilton Building opened, many architecturally interesting buildings designed by internationally known architects have been added to the Denver landscape, such as the Museum of Contemporary Art by David Adjaye or the Clyfford Still Museum by Allied Works Architecture. Denver has also added two official cultural districts, and murals abound throughout the city. To say that the Hamilton Building caused such changes is certainly giving too much agency to a single building project; but the work that the Denver Art Museum invested in fostering dialogue about art and architecture within the city contributed to Denver being a center for arts and culture. Iconic buildings can strive to both drawing global capital and tourism and simultaneously supporting local goals.

As scholars continue to explore the nuances of iconic architecture and its effect on urban issues, it is important to consider who the audiences are for any project. As we study the successes and failures of flagship architecture, it is important to attend to who the audience is meant to speak to, who the intended audience is. This will give a richer understanding of the 
ways in which buildings can operate on multiple levels, both increasing local pride and

simultaneously drawing international tourism.

\section{References}

Aguilar, Louis. 2002. “A Boon to Culture, City.” Denver Post, March 17, sec. K. Denver. Arts. Denver Art Museum. Redevelopment. Denver Art Museum Clippings File at the Denver Public Library.

Barnes-Gelt, Susan. 2006. "Playing All the Angles: Art Museum’s Twice-In-A-Lifetime Opportunity.” Denver Post, September 17, sec. E. Denver. Arts. Denver Art Museum. Hamilton Building. Open 10/2006. Denver Art Museum Clippings File at the Denver Public Library.

Booth, Michael. 2003. “It May Be Art, But Can We Live With It?” Denver Post, August 20, sec. F. Denver. Arts. Denver Art Museum. 2000-2009. Denver Art Museum Clippings File at the Denver Public Library.

Brawne, Michael. 1998. The Getty Center: Richard Meier \& Partners. Architecture in Detail. London: Phaidon.

Brenner, Neil, and Roger Keil, eds. 2006. The Global Cities Reader. London: Routledge.

Carman, Diane. 2005. “Let Museum Be a Point of City Pride.” Denver Post, April 17, sec. C. Denver. Arts. Denver Art Museum. 2000-2009. Denver Art Museum Clippings File at the Denver Public Library.

CBS News. 2010. “America’s Most - and Least - Educated Cities.” CBS.com, October 1. http://www.cbsnews.com/stories/2010/10/01/national/main6918307.shtml.

Chandler, Mary Voelz. 2000. “Model to Reveal Shape of a Wing to Come.” Rocky Mountain News, November 5, sec. D. Denver. Arts. Denver Art Museum. Denver Art Museum Clippings File.

Chandler, Mary Voelz. 2001. “Art Museum Expansion Design Unveiled.” Rocky Mountain News, February 22, sec. A. Denver. Arts. Denver Art Museum. Denver Art Museum Clippings File.

Clark, Terry N., ed. 2004. The City as an Entertainment Machine. Research in Urban Policy, v. 9. Amsterdam; London: JAI.

Clarke, Susan E., and Gary L. Gaile. 1998. The Work of Cities. Globalization and Community, v. 1. Minneapolis: University of Minnesota Press.

Dicks, Bella. 2004. Culture on Display the Production of Contemporary Visitability. Berkshire, England: Open University Press.

Ditmer, Joanne. 2000a. “Three Visions One Site: Art Museum Architect to Be Named Thursday.” Denver Post, July 9, sec. I. Denver. Arts. Denver Art Museum. Denver Art Museum Clippings File.

Ditmer, Joanne. 2000b. “Winging It: Art Museum Architects Works All the Angles.” Denver Post, August 24, sec. E. Denver. Arts. Denver Art Museum. 2000-2009. Denver Art Museum Clippings File at the Denver Public Library.

Domosh, Mona. 1996. Invented Cities: The Creation of Landscape in Nineteenth-Century New York \& Boston. New Haven: Yale University Press. 
Duncan, Carol. 1995. Civilizing Rituals: Inside Public Art Museums. Routledge.

Dunn, Julie. 2006a. “City Sees Draw in Culture.” Denver Post, August 27, sec. K. Denver. Arts. Denver Art Museum. Redevelopment. Denver Art Museum Clippings File at the Denver Public Library.

Dunn, Julie. 2006b. “Voters Helped Create Funding Momentum.” Denver Post, October 6, sec. J. Denver. Arts. Denver Art Museum. Hamilton Building. Open 10/2006. Denver Art Museum Clippings File at the Denver Public Library.

Dunn, Julie. 2006c. “Arty Parties.” Denver Post, October 10, sec. C. Denver. Arts. Denver Art Museum. Hamilton Building. Open 10/2006. Denver Art Museum Clippings File at the Denver Public Library.

Erickson, Bill, and Marion Roberts. 1997. "Marketing Local Identity.” Journal of Urban Design 2 (1): 35-59. doi:10.1080/13574809708724395.

Filler, Martin. 2006. “Manifest Destination: Daniel Libeskind's Dazzling Addition to the Denver Art Museum Is the Latest Bid to Use Exhibitionist Design as a Tourist Magnet.” House + Garden, November.

Florida, Richard L. 2005. Cities and the Creative Class. New York: Routledge.

Fraser, Andrea. 2006. "Isn't This a Wonderful Place? (A Tour of a Tour of the Guggenheim Bilbao).” In Museum Frictions: Public Cultures/Global Transformations, edited by Ivan Karp, Corinne A. Kratz, Lynn Szwaja, and Tomas Ybarra-Frausto, 135-60. Durham: Duke University Press.

Fyfe, Gordon. 1996. “A Trojan Horse at the Tate: Thorizing the Museum as Agency and Structure.” In Theorizing Museums: Representing Identity and Diversity in a Changing World, edited by Sharon MacDonald and Gordon Fyfe, 203-28. Sociological Review Monograph Series. Cambridge, Mass: Blackwell.

Gospodini, Aspa. 2004. "Urban Morphology and Place Identity in European Cities: Built Heritage and Innovative Design.” Journal of Urban Design 9 (2): 225-48. doi:10.1080/1357480042000227834.

Greenberg, Miriam. 2008. Branding New York: How a City in Crisis Was Sold to the World. New York: Routledge.

Grodach, Carl. 2008. "Museums as Urban Catalysts: The Role of Urban Design in Flagship Cultural Development.” Journal of Urban Design 13 (2): 195-212. doi:10.1080/13574800801965742.

Grodach, Carl. 2016. "Mapping the Arts: Industry Concentrations, Distribution, and Change in the US, 1980-2010.” International Journal of Cultural Policy 22 (3): 353-75. doi:10.1080/10286632.2014.987667.

Grodach, Carl, and Anastasia Loukaitou-Sideris. 2007. "Cultural Development Strategies and Urban Revitalization.” International Journal of Cultural Policy 13 (4): 349-70. doi:10.1080/10286630701683235.

Guasch, Ana Maria, and Joseba Zulaika. 2005. “Introduction.” In Learning from the Bilbao Guggenheim, edited by Ana María Guasch and Joseba Zulaika, 7-18. Center for Basque Studies Conference Papers Series, no. 2. Reno, Nev: Center for Basque Studies, University of Nevada, Reno.

Hannigan, John. 1998. Fantasy City: Pleasure and Profit in the Postmodern Metropolis. London: Routledge. 
Harris, Neil. 1996. “Searching for Form: The Denver Art Museum in Context.” In The Denver Art Museum: The First Hundred Years, edited by The Denver Art Museum, 21-54. Denver, Colorado: The Denver Art Museum.

Heathcote, Edwin. 2006. "Not Just Another Cow Town.” The Financial Times, October 25. Henderson, Justin. 1998. Museum Architecture. Gloucester, Mass. : Cincinnati, Ohio: Rockport Publishers ; Distributed to the book trade and art trade in theUnited States by North Light Books.

Holliday, Kate. 2009. "Whose City Hall Is It? Architecture and Identity in New Orleans.” Journal of Urban Design 14 (3): 279-308. doi:10.1080/13574800903056499.

Isenberg, Barbara S, and Frank O Gehry. 2009. Conversations with Frank Gehry. New York, NY: Alfred A. Knopf.

Jencks, Charles. 2005. The Iconic Building. New York, NY: Rizzoli.

Jencks, Charles. 2006. “The Iconic Building Is Here to Stay.” City 10 (1): 3-20. doi:10.1080/13604810600594605.

KDTV Channel 8. 2001. “Channel 8 Program Guide,” March. Denver. Arts. Denver Art Museum. Denver Art Museum Clippings File.

King, Anthony D. 1991. Global Cities: Post-Imperialism and the Internationalization of London. International Library of Sociology. London; New York: Routledge.

Klingmann, Anna. 2007. Brandscapes: Architecture in the Experience Economy. Cambridge, Mass: MIT Press.

Krakauer, Jon. 1993. “Denver: The Cow Town with Culture, and Proud of It.” The Smithsonian, September. Denver. Arts. Denver Art Museum. 1990-1999. Denver Art Museum Clippings File at the Denver Public Library.

Lasansky, D. Medina, and Brian McLaren, eds. 2004. Architecture and Tourism: Perception, Performance, and Place. English ed. Oxford; New York: Berg.

Lefebvre, Henri. 1996. “The Right to the City.” In Writings on Cities, translated by Elonore Kofman and Elizabeth Lebas, 63-181. Malden: Blackwell.

. 2011. The Production of Space. Malden: Blackwell.

Libeskind, Daniel. 2004. Breaking Ground: [Adventures in Life and Architecture]. New York: Riverhead Books.

MacMillan, Kyle. 2003a. “Libeskind Raises DAM’s Profile.” Denver Post, March 9, sec. F. Denver. Arts. Denver Art Museum. Redevelopment. Denver Art Museum Clippings File at the Denver Public Library.

MacMillan, Kyle. 2003b. “Architect Libeskind Knows Sales Savvy Is the Art of the Deal.” Denver Post, April 13, sec. F. Denver. Arts. Denver Art Museum. Redevelopment. Denver Art Museum Clippings File at the Denver Public Library.

MacMillan, Kyle. 2005. “Outside View: The New Public Engagement.” Oculus 67 (3).

Mccarthy, John. 2006. "Regeneration of Cultural Quarters: Public Art for Place Image or Place Identity?” Journal of Urban Design 11 (2): 243-62. doi:10.1080/13574800600644118.

McClellan, Andrew. 1999. Inventing the Louvre: Art, Politics, and the Origins of the Modern Museum in Eighteenth-Century Paris. Berkeley: University of California Press.

McNeill, Donald. 2009. The Global Architect: Firms, Fame and Urban Form. New York: Routledge.

Message, Kylie. 2006a. New Museums and the Making of Culture. Oxford, UK: Berg.

Message, Kylie. 2006b. “The New Museum.” Theory, Culture \& Society 23 (2-3): 603-6. 
Moxey, Keith. 2005. “Gehry’s Bilbao: Visits and Visions.” In Learning from the Bilbao Guggenheim, edited by Ana María Guasch and Joseba Zulaika, 173-84. Center for Basque Studies Conference Papers Series, no. 2. Reno, Nev: Center for Basque Studies, University of Nevada, Reno.

Murray, Jon. 2017. "Denver Population Boom Slows down -- a Little -- as the City Nears 700,000 Residents.” Denver Post, March 28, sec. Colorado News. http://www.denverpost.com/2017/03/28/denvers-growth-spurt-slows-down/.

Newhouse, Victoria. 2006. Towards a New Museum. Expanded ed. New York: Monacelli Press.

Nicholson, Louise. 2006. “The Denver Art Museum: Not Just a One-Minute 'wow.”” Apollo 164 (536).

Ockman, Joan. 2004. “New Politics of the Spectacle: 'Bilbao’ and the Global Imagination.” In Architecture and Tourism: Perception, Performance, and Place, edited by D. Medina Lasansky and Brian McLaren, English ed, 227-40. Oxford; New York: Berg.

Palmer, Joni M. 2012. “The Politics Of 'the Public': Public Art, Urban Regeneration and the Postindustrial City - the Case of Downtown Denver.” Ph.D., United States -- Colorado: University of Colorado at Boulder. https://search.proquest.com/docview/1095131493/abstract/1E24CFBF90B04239PQ/1.

Patterson, Matt. 2012. "The Role of the Public Institution in Iconic Architectural Development." Urban Studies 49 (15): 3289-3305. doi:10.1177/0042098012443862.

Plaza, Beatriz. 2000. "Evaluating the Influence of a Large Cultural Artifact in the Attraction of Tourism The Guggenheim Museum Bilbao Case.” Urban Affairs Review 36 (2): 264-74. doi:10.1177/10780870022184859.

Plaza, Beatriz. 2006. “The Return on Investment of the Guggenheim Museum Bilbao.” International Journal of Urban and Regional Research 30 (2): 452-467. doi:10.1111/j.1468-2427.2006.00672.x.

Plaza, Beatriz. 2007. “The Bilbao Effect (Guggenheim Museum Bilbao).” Museum News 86 (5): 13-19.

Plaza, Beatriz. 2008. “On Some Challenges and Conditions for the Guggenheim Museum Bilbao to Be an Effective Economic Re-Activator.” International Journal of Urban and Regional Research 32 (2): 506-517. doi:10.1111/j.1468-2427.2008.00796.x.

Pojani, Dorina, and Dominic Stead. 2015. "Urban Planning and Design as Verbal and Visual Rhetoric.” Journal of Urban Design 20 (5): 582-614. doi:10.1080/13574809.2015.1071653.

Reuteman, Rob. 2004. "Museum Awes Me, and Ex-Builder.” Rocky Mountain News, September 18, sec. C. Denver. Arts. Denver Art Museum. Redevelopment. Denver Art Museum Clippings File at the Denver Public Library.

RMJM Hillier Communications Department. 2008. “American’s Best Cities for Design.” online. http://featuresblogs.chicagotribune.com/theskyline/files/americas_best_cities_for_design rmjm_hillier.pdf.

Rybczynski, Witold. 2002. “The Bilbao Effect.” The Atlantic Monthly, September. www.theatlantic.com/past/docs/issues/2002/09/rybczynski.htm.

Schulze, Franz. 2001. “Disclosing Santiago Calatrava’s Milwaukee Masterpiece.” In Building a Masterpiece: Milwaukee Art Museum, by Milwaukee Art Museum, 1st ed, 21-41. New York: Hudson Hills Press in association with Milwaukee Art Museum : Distributed in the U.S. by National Book Network. 
Science and Cultural Facilities District. 2009. “Celebrating 20 Years: SCFD 1989-2009.” The Publishing House.

Sharp, Lewis, and Frederic C. Hamilton. 2000. “Annual Report 1999-2000, Year in Review.” Denver Art Museum. Denver Public Library.

Sinisi, J. Sebastian. 2000. “Art Museum Addition Unveiled--Conceptually.” Denver Post, August 17, sec. B. Denver. Arts. Denver Art Museum. 1990-1999. Denver Art Museum Clippings File at the Denver Public Library.

Sklair, Leslie. 2005. "The Transnational Capitalist Class and Contemporary Architecture in Globalizing Cities.” International Journal of Urban and Regional Research 29 (3): 485500.

Spaans, Marjolein. 2004. "The Implementation of Urban Regeneration Projects in Europe: Global Ambitions, Local Matters.” Journal of Urban Design 9 (3): 335-49. doi:10.1080/1357480042000283887.

Tilden, Scott J. 2004. "Preface.” In Architecture for Art: American Art Museums, 1938-2008, 79. New York: H.N. Abrams.

Travelandleisure.com, CNN Headline News, and Pearson Education, Inc. 2008. "Best Architecture in U.S. Cities.” Infoplease. http://www.infoplease.com/us/cities/bestarchitecture.html.

US Census Bureau. 2010. “2010 Census Population and Housing Tables.” http://www.census.gov/population/www/cen2010/cph-t/cph-t-5.html.

Wansborough, Matthew, and Andrea Mageean. 2000. “The Role of Urban Design in Cultural Regeneration.” Journal of Urban Design 5 (2): 181-97. doi:10.1080/713683962.

West, Mark. 2006. "Edifice Complex: Museums Spend Fortunes on Trophy Buildings, but Are They Really Worth It?” W Magazine, November.

Witcomb, Andrea. 2003. Re-Imagining the Museum : Beyond the Mausoleum. London;;New York: Routledge.

Zukin, Sharon. 1991. Landscapes of Power: From Detroit to Disney World. Berkeley: University of California Press.

Zulaika, Joseba. 2003. Guggenheim Bilbao Museoa: Museums, Architecture, and City Renewal. Basque Textbooks Series. Reno: Center for Basque Studies, University of Nevada. 